\title{
FOLKLORE AS NATIONAL THOUGHT IN AZERBAIJAN CHILDREN'S LITERATURE (BASED ON MATERIALS FROM THE SECOND HALF OF THE $20^{\mathrm{TH}}$ CENTURY)
}

Summary. At the second part of $20^{\text {th }}$ century the Azerbaijan children's literature is very rich with the genre typology and theme colours. The most important problem is about the determination of folklore resources in the children's literature. The folklore as a resource of idea-aesthetic thought embraced whole sides of ethnos, genetic memory and contemporary environment. So, that at the second period of the last century with purposely and continuously also systematically appealed to the children's literature. The creativity of S. Rahimov, Mir Jalal, A. Valiyev, M. Dilbazi, A. Abbasov, G. Ilkin, S. Valiyev, M. Rzaguluzadeh, Anar, Elchin, M. Ibrahimbayov, R. Ibrahimbayov, I. Malikzadeh, X. Hasilova, N. Suleymanov, A. Babayeva, A. Samadli and others could be sample to our sayings. All these gives us bases to say that the use of folklore in children's publications in the target order stands on the leading positions.

One of the most important aspects of the success of the Azerbaijani children's literature in the second half of the twentieth century is that it is dominated by folklore and the rich spiritual culture of the people. Folklore has been one of the main sources of literary thinking throughout history. The rich spiritual culture of the people, the system of values that has been forming for thousands of years, behavioral labels, moral norms, and the whole archetype of memory are realized in folklore, or rather preserve their existence in folklore. The passion for the existence, the artistic and intellectual foundation of the ethnos can be realized through words and art. National memory is, in fact, an event of self-expression of the people and ethnicity. The second half of the twentieth century is interesting in the development of Azerbaijani literature with its peculiarities, styles and diversity of thinking. Enrichment in prose, poetry, drama, publicity, literary criticism is an example of this. In this age, children's literature has already attracted attention, including the success of previous decades, as well as the preference for new searches. Children's literature has always enriched in this regard. Azerbaijan children's literature already has a sufficiently folklore text base. Our talented masters have repeatedly tested their ability in this direction and have had many successful results.

Key words: Azerbaijan literature of $20^{\text {th }}$ century, tales, fairy tales-poems, traditions and modernity.

Introduction. The second half of the twentieth century is a special stage in the rich and successful development of children's literature in Azerbaijan. The main features that characterize this stage are the tendency to deviate from political and ideological fetters, to bring the national spirit to the forefront, to give preference to nationalhistorical traditions and folklore. Azerbaijani literature has always been characterized by richness, the emergence of classical literature, the emergence of original thinkers in the artistic field, searches and discoveries. The second half of the twentieth century is interesting in the development of Azerbaijani literature with its peculiarities, styles and diversity of thinking. Enrichment in prose, poetry, drama, publicity, literary criticism is an example of this. In this age, children's literature has already attracted attention, including the success of previous decades, as well as the preference for new searches. Children's literature has always enriched in this regard. The source of this enrichment is the rich folk culture of the people and the magnificent monuments created by classics. Folklore is the foundation and the source for all artistic thinking. One of the most important aspects of the success of the Azerbaijani children's literature in the second half of the twentieth century is that it is dominated by folklore and the rich spiritual culture of the people. Folklore has been one of the main sources of literary thinking throughout history. The rich spiritual culture of the people, the system of values that has been forming for thousands of years, behavioral labels, moral norms, and the whole archetype of memory are realized in folklore, or rather preserve their existence in folklore. The passion for the existence, the artistic and intellectual foundation of the ethnos can be realized through words and art. National memory is, in fact, an event of self-expression of the people and ethnicity. For this reason, classics have always preferred to use national traditions and folk qualities and acknowledged it as a source of creativity.

Discussion. Azerbaijan children's literature already has a sufficiently folklore text base. Our talented masters have repeatedly tested their ability in this direction and have had many successful results. Tongue-twisters, children's games, children's performances, riddles, lullabies, mournings, children's songs, "sanama", "duzgu", "ojashma", fairy-tales and etc. are a rich and colorful cultural event. The didactic examples of the works of X. Shirvani, N. Ganjavi, M. Fuzuli and other classics also take into account the general spirit of children. A. Bakikhanov, M. Vazeh, Q. Zakir, S. Shirvani,A. Shaig, S. Ganizadeh, A. Sahhet, M. Sabir, S. Akhundov, R. Afandiyev and others have always paid attention on the creation of artistic examples for children. Thus, the path taken by these great literary representatives has resulted in the formation of a rich children's literature. An important part of this wealth is related to the Soviet era. Union-wide decades, congresses, discussions on the problems of children's literature contributed to the formation of the younger generation. For instance, "the First Azerbaijan Children's Literature Conference" (1931), "On the Reorganization of Literary and Art Organizations" (1932), "On the Creation of Children's Literature Publishing House" (1933) and etc. are samples of it. The main issue was to create children's literature that based on the Soviet man. "Şəngülüm, Şüngülüm, Məngülüm" ("Shangul, Mangul, Shungul") (1934), "Kondli və ilan"("Peasant 
and snake”) (1935), "Küləklər" ("Winds”), "Məktəb şərqisi” ("School oriental"), "Zəhra üçün" ("For Zahra") by M. Mushfig, "Sunbulum", "Deyin, gulun, ovladlarim", "A kohlan atım" by S. Vurgun, "Nargiz", "Jeyran", "Oyunchu bagalar" by M. Seyidzadeh "Qeyrot" (honor), "Zarifa" by T. Sumurg, "Nənəmin cəhrəsi", "Madarın dastanı" by A. Valiyev, "Bığlı ağa", "Şor cüllütü" by S. Valiyev and etc. are examples that respond to children's imaginations, thoughts, or rather to children's interests. In one of the letters of the famous literary critic F. Kocharli (May 26, 1911) to A. Shaig, he emphasizes one point: "The brochures you sent came and made me very happy. Works that are written in such a simple language and the theme is taken from our own lives $\langle\ldots\rangle$ fairy tales and stories written for small children can be useful if they are easy and simple, written in an open language and close to the children's spirit" $[5$, p. 403]. Apparently, what is written here is, in essence, a priority for folklore and public life and seems to be a challenge. In the second half of the twentieth century, this trend is also in the spotlight. As you know, literature of the sixties of the last century is important with the tendency of content, thinking and leading of national spirit. Already existing type of thinking, the Soviet man's formula is characterized by a preference for national traditions and ethnos. One of the most important directions here, and perhaps most importantly, is breaking the boundaries of the type of thinking that has been established in previous decades and linking everyone to the national tradition. As it is known, the Soviet literature is characterized by richness, diversity and developmental diversity. Children's literature is also a part of this great literature, and it is always considered a tradition as an integral part of artistic thinking, because of its specificity and overall spirit. The creativity of the artists such as H. Alibeyli, T. Elchin, A. Karim, T. Mutallibov, I. Tapdig, H. Ziya, M. Guner, F. Sadiq, M. Aslan, Z. Khalil, T. Mahmud (poetry), H. Hasilova, A. Babayeva, N. Suleymanov, A. Ahmedova (prose), Y. Azimzade, A. Samadli (dramaturgy) has taken their origin from folklore, in essence. "What is the reason for such a powerful influence of folk art on children's literature, and the close and inseparable connection between these two literary arsenals? Why was there a need to start with folklore when it was necessary to create literature for the younger generation in written literature - and why did the children literature fail to communicate with folklore throughout its development?

Certainly, the first sign of the answer to this question must be sought in the strange relation between the rich fantasy of folk literature and the romantic nature of the child. In fact, life is a fairy tale for a child. It is not known where life ends and where the tale begins. The child finds answers to all sorts of problems and challenges in a fairy tale. With the boundlessness of the fairy-tale fantasy, the boundless dimensions of the child's world are balanced with one another" [4, p. 50-51]. That is why, in the second half of the $20^{\text {th }}$ century, thanks to the rich folk culture, the artists preferred to create artistic designs for national thought. Tales, legend, fable, story and myth elements began to follow artistic thinking as a system. Let us also add that the writing and thinking patterns defined by the Soviet era in the general spirit of literature led to revision and different approaches. Rather than following the principles of the ideological system, the tendency for centrifugalism to be strengthened. The idea of brotherhood and friendship of nations gave preference to the values that genetic memory determined and preserves. In fact, in the literature of Azerbaijan the works of tradition, containing national thought, have been in existence for decades. In their essence, they represented national thinking in various forms, in the person of certain images, in the form of events and motives. "There were a lot of folk-motivated and modern thematic works in the field of Azerbaijani

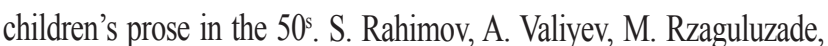
M. Ibrahimov, M. Jalal, A. Mammadkhanli, H. Abbaszade, G. Ilkin and others created interesting works. Published works "Pori çinq1lı" by S. Rahimov, "Hekayələr" by A. Valiyev, "Ovçu Elişlə qoçaq Aytəkin nağılları" by M. Rzaquluzadeh, "Çandranın üsyanı” by M. Ibrahimov, "Yaşıdlarım", "Yuxu və külək" M. Jalal, "Üçtəpə uşaqları" Q. İlkin, "Balaca nərgiz" by A. Mammadkhanli, "Bacı və qardaş", "Şəlalə" by H. Abbaszadeh, "Kamalın ad günü", "Gülzar" by H. Ibrahimov show a literary view of these years" [3, p. 206]. Therefore, the stage after the second half of the twentieth century cannot be taken away from the whole tradition and be analyzed in a completely different way. Certainly, the process in the Azerbaijani literature from the end of the XIX century and the beginning of the XX century, the creation of samples for the preservation and awakening of multicultural spiritual memory, the priority of folk culture in the education of the people was in the memory of the environment. In the later decades of the twentieth century, as well as in the Soviet era, literature was searching for different forms and methods for maintaining that spirit. There was an exchange of national memory that M. Akhundov, H. Zardabi, S. Shirvani, Y. Chamanzamli, S. Akhundov, A. Sahhat, A. Shaig, U. Hajibeyov, J. Mammadguluzade, S. Huseyn, M. Mushfig and others carried in different forms. Its source was undoubtedly folklore, a moral code and a code of conduct that has been shaped by the people for thousands of years. The memory of the second half of the twentieth century was reflected in the general spirit of the child's prose.

For example, M. Rzaguluzadeh's appeal to "Kitabi Dada Gorgud" epics and writing works based on motives, events and themes are influences of children's literature on folklore. As it is known, "Kitabi Dada Gorgud" has always been influenced by the literature as a phenomenon of Azerbaijani literature and artistic thinking of Turkic peoples as a whole. At various stages (more often in the second half of the twentieth century) our epics "Kitabi Dede Korkut", "Koroglu", "Gachag Nabi", "Gachag Kerem", "Gachag Tanriverdi", as well as fairy tales, fables and legends, have become a source of literature, form of expression, and fact of the subject. M. Rzaguluzadeh also wrote the stories "Ana ürəyi, dağ çiçəyi”," "El gücü", "Dəli Ozan". The story "Ana ürəyi, dağ çiçəyi" is based on the book "Dirsə xan oğlu Buğacın boyu" in the books "Kitabi Dada Gorgud". "Horns, clarions, drums were played. The wrestlers wrestled. The horsemen raced, passed, ozans wrangled $\langle\ldots>$. By the end of the holiday, the time for the most exciting entertainment has come.

The khan's calf, fed for nine months in the dark basement, was appeared. The bull was a bull that turned its horn into a stone, turned it dust, and when it hit its claw, it burned. Three wrestlers were holding the chain on the bull's horn from the right and three wrestlers from the left. That bull will fight with horn bull like himself.

The bull shook his head at the cliff, broke his chain, and ran to the arena. Everyone cried out in horror and stood still in the freezer. nervous bull the bull saw the colors of the trout where girls and women were sitting and rolled right there.

Now, probably, blood would be shed, people would die, and the feast would turn black.

Everyone, even the armed guards, was shocked and lost. Suddenly, at the age of fifteen or sixteen, a boy emerged with a tiger agility, plunging himself on the bull $<\ldots>$ ". [1, p. 31]. As it turns out, this is a new form and purely national style, with the development of "Dirsa khan oglu", "Buğac boyu". Here the author's opinion is based on national memory, a typical episode of the heroic history of the nation and its age. The writer created an original example using epic traditions, 
and introduced the idea of raising the young generation in the spirit of bravery and heroism. The story of "El gücü" is based on "Qazan xanın evinin yaşmalanması boyu" ("The robbery of Kazan khan's house"). The story of "Xan çinarın yarpağı" ("Leaves of the Khan chinar") is also based on the general spirit and content of those who are in the public memory and expressions of their imagination. As it is known, there are many stories and episodes about "khan chinar" among the people. The writer also appealed to him, not accidentally, and wrote an interesting story. Chinar points to such values as highness, pride, self-importance, indifference in people's memory. In the story, the feelings and thoughts of the little girl who took the yellow leaves of the khan's chinar are written. Seeing the girl becoming sad, leaves come to her and tell her his story about life and the chinar.

In the $60^{\mathrm{s}}$ and $80^{\mathrm{s}}$ of the last century, the children's prose was represented by the older generation (S. Rahimov, Mir Jalal, A. Valiyev, A. Abbasov, G. Ilkin, S. Valiyev, M. Rzaguluzade) and the creativity of the new generation of literature (Anar, Elchin, M. Ibrahimbeyov, R. Ibrahimbeyov, I. Malikzade, H. Hasilova, N. Suleymanov, A. Babayeva, A. Samadli) at that time. In their works, they sought to violate the principles of the existing ideology by addressing the genres of folklore, legend, legend, saga, fairy tales and images (systematic and consistent), as well as by dominating national values. Children stories such as "Yağı̧ kəsdi" by Anar, "Min gecədən biri", "Gümüşü, narıncı", "Günay, Yalçın, Nigar, bir də bir Səlim" by Elchin, "Uşaqlığın son geçəsi” M. Rustambeyov, "Səhranın bəyaz gecəsi” R. Ibrahimbeyov, "Özgə anası" I. Malikzadeh, "Ilkinin anası", "Usta qıy-qıy”, "Uşaqların söhbətləri”," "Sarıdaş kəndinin uşaqları" by M. Aslan, "Ballıca", "Çıraq nənənin nağılları", "Cırtdanla Azmanın yeni sərgüzəştləri", "Dünyanın ən balaca nağılları" "Salam, Cirtdan", X. Hasilovanın "Nailənin kubikləri", "İlk məktub", "Qarının hədiyyəsi”, "Baba və nəvə", "Nənəm məktəbdədir", "Krançı və sərçə yuvası" by Z. Khalil, "Nənəcan, nağıl de", "Böyürtkən mürəbbəsi”, "Gülaçarın kuklası", "Qız Kamil”, "Qızılı buzov" A. Babayeva, "Sədəfli saz", "Qoruqçu", "Yetər nənə" N. Suleymanov and etc. with their originality, folklore style and content reflect the view of the second half of the twentieth century and beyond. As it turned out, "flexible subjects, sweet language, smoothly drawn characters, memorable images, eventfulness, inner dynamics, unexpected situations, abundance of artistic expressions, rich fantasy, optimistic spirit, elegant humor and etc. are what make love children of folk literature. As it turns out, folklore, with its vast and accessible capabilities, promises a lot for children's literature. Indeed, communication between them is multidisciplinary, and multidimensional " [4, p. 51]. Therefore, in the second half of the last century, references to folklore traditions have been increasing, and the expression of national spiritual values has found its place in the children's prose in various forms. For example, the story of A. Babayeva's "Nənələr < .. > əfsanələr" ("Grandmothers $<\ldots>$ myths") draws attention from the point of view of its original development, the transport and expression of fairy tales formules. The story is about the great Azerbaijani poet S. Vurgun. The conversation between the grandmother and the grandchildren in front of the poet's statue reflects the tale. At the end of the story, there is an episode that will be typical. It says: "As I listened to the story of the grandmother Malak, I was thinking of the legends that would fall into the language one hundred years later, not fifty. I was thinking of myths and tales that flowed directly into our hearts and memories from the soft, wrinkled lips of my grandmothers.

It seems to me that not only fairy tales, legends, bayatis, lullabies, mournings that adorn our childhood and our entire lives are all poured out of our grandmother's toothless mouth and wrinkled lips.
Thank you, thank you, our wise, grandmothers <...> Grandmothers who gave us the first noble, loving lesson, generously widened our heart, evoked good feelings < .. > " [2, p. 299]. As can be seen, the second half of the twentieth century has shaped the creation of original artistic patterns in Azerbaijan's children's artistic prose, based on folk thinking, a system of national and moral values, and folk culture. The most important aspect here is the inclination of the qualities based on the preservation of moral values, genetic memory of ethnos the tendency for future generations. All this is a process that begins with the awakening of national thought and is a leading and even more selfevident issue in children's prose.

\section{References:}

1. Abdulla B., Rustambayli S., Huseynli S. Literature. Baku : Çashıglu, 2000. P. 286

2. Babayeva A. Out of the wind. Baku : Ganjlik, 1983. P. 356.

3. Khalil Z., Asgarli F. Children literature. Baku : ADPU, 2011. 498 p.

4. Mammadov M., Babayev Y., Cavadov T. Pedagogical environment and children's literature. Baku : Maarif, 1992. 288 p.

5. Shaig A. Works. 5 vol. $5^{\text {th }}$ v. Baku : Yazıchı, 1978. P. 476.

Алісва Р. Фольклор як національна думка в дитячій літературі Азербайджану (за матеріалами другої половини XX століття)

Анотація. У другій половині XX століття азербайджанська дитяча література дуже багата жанрової типологією i тематичними напрямами. Найважливішою проблемою $\epsilon$ визначення фольклорних ресурсів у дитячій літератуpi. Фольклор як джерело ідейно-естетичної думки охопив особливості етносу, генетичної пам'яті та сучасного середовища. Так, у другому періоді минулого століття митці цілеспрямовано та систематично зверталися до дитячої літератури. Творчість С. Рагимова, Світ Джалала, А. Валієва, М. Дільбажі, А. Аббасова, Г. Ількіна, С. Валієва, М. Рзагулу-заде, Анара, Ельчина, М. Ібрагімбекова, Р. Ібрагімбекова, І. Малік-заде, Х. Гасилова, Н. Сулейманов, А. Бабаєва, А. Самадлі та інших може бути прикладом вищезазначеного. Усе це дає нам підставу стверджувати, що фольклорні мотиви в дитячих виданнях мають провідні позиції.

Одним із найважливіших аспектів успіху азербайджанської дитячої літератури у другій половині ХХ століття $є$ те, що в ній переважає фольклор і відбито багату духовну культуру народу. Фольклор був одним з основних джерел літературного мислення протягом всієї історії. Багата духовна культура людей, система цінностей, яка формувалася протягом тисячоліть, поведінкові моделі, моральні норми і весь архетип пам'яті реалізуються у фольклорі, або, імовірніше, зберігаються у фольклорі. Пристрасть до існування, художня й інтелектуальна основа етносу можуть бути реалізовані через слово і мистецтво. Національна пам'ять - це, по суті, акт самовираження народу й етнічної приналежності. Для другої половини XX століття характерний розвиток азербайджанської літератури, зі своїми особливостями, стилями та різноманітністю мислення. Збагачення прозою, поезією, драмою, літературною критикою - тому приклад. У ті часи дитяча література вже привертала увагу митців, зокрема успіхи попередніх десятиліть, а також нові пошуки. Дитяча література завжди збагачувалася в цьому плані. Азербайджанська дитяча література вже має достатню фольклорну базу даних. Наші талановиті майстри неодноразово випробовували свої здібності в цьому напрямі та мали багато успішних результатів.

Ключові слова: азербайджанська література XX століття, казки, казки-поеми, традиції, сучасність. 